\author{
Плешивцева Анна Алексеевна
}

\title{
АКТУАЛИЗАЦИЯ ПОЛИТИКИ УПРАВЛЕНИЯ ЗОЛОТЫМИ АВУРАМИ В УСЛОВИЯХ ЭКОНОМИЧЕСКИХ И ПОЛИТИЧЕСКИХ ТРАНСФОРМАЦИЙ МИРОВОЙ ФИНАНСОВОЙ СИСТЕМЫ
}

Сегодия все больиее число экспертов и аналитиков склоняются к сиенарию трансфориации глобальной экономики, при котором американская валюта перестанет играть роль ведуцей резервной расчетной единицы планеть. В свете регулярно возникающцх финансовых кризисов, имеющих с каждым разом все более тяжелье последствия для экономик отдельных стран и даже регионов, актуализируется вопрос о строительстве нового финансового миропорядка, а также платежных инструментах и средствах, его поддерживающих. B этой связи будущая финансовая архитектура предполагает пересмотр роли золота, которое по сей день продолжсает быть моицыц финансовыми ориентиром для государств в ходе осуществления экономической и политической деятельности.

Ключевые слова: трансформация валютно-финансовой системы, гегемония доллара, монетарное золото, золотовалютные резервы, укрепление национальной валюты.

\section{Anna Pleshivtseva \\ ACTUALIZATION OF GOLDEN AURY'S GOVERNANCE POLICY \\ IN THE CONDITIONS OF ECONOMIC AND POLITICAL TRANSFORMATIONS OF THE WORLD FINANCIAL SYSTEM}

Today, an increasing number of experts and analysts are inclined to the scenario of transformation of the global economy, in which the US currency will cease to play the role of the leading reserve unit of the planet. In the light of the regularly occurring financial crises, which each time have more severe consequences for the economies of individual countries and even regions, the question of building a new financial world order, as well as payment instruments and funds supporting it, is being updated. In this regard, the future financial architecture assumes a revision of the role of gold, which to this day continues to be a powerful financial guide for states in the course of their economic and political activities.

Key words: transformation of the monetary and financial system, hegemony of the dollar, monetary gold, gold and foreign exchange reserves, strengthening of the national currency.

Bвedeниe / Introduction. Существующая концепция американоцентризма с каждым годом теряет своих сторонников на фоне дискредитирующих валютно-финансовую систему процессов, основанных на безоговорочном превалировании доллара США в международных расчетах. Ямайскую систему предлагается видоизменить в различных вариантах: установление многовалютного стандарта, базирующегося на применении наиболее «ходовых» в мировой экономике национальных денежных единиц; учреждение региональных финансовых систем, основанных на расчетах в валютах стран одного региона, возрождение золотого стандарта; формирование многотоварного стандарта.

Преддверием трансформации нынешней финансово-валютной системы являются процессы формирования новых экономически и финансово сильных центров, начинающих противостоять политике США, Западной Европы и Японии. Заметную роль в этих процессах играет изменившаяся стратегия крупных государств в сфере золотовалютных резервов, особенно в отношении монетарного золота.

Россия в течение последних нескольких лет демонстрирует стремление к наращиванию своих золотых авуаров. Нельзя исключать, что государственная политика РФ в отношении золота соотносится с политикой государств, стремящихся противостоять текущему положению дел. Так, эксперты видят определенную согласованность в мерах по увеличению золотых государственных запасов России и КНР. 
Предметом настоящей статьи является анализ процессов, происходящих на мировой экономической арене в сфере управления официальными золотыми резервами, а также в части ухода от долларовой зависимости.

Maтериалы и методы / Materials and methods. В ходе постулирования направления и структуры исследования использовался абстрактно-логический метод. При выявлении основных характеристик мировой валютно-финансовой системы использовались методы сравнений, системного анализа и синтеза. Для систематизации полученной информации и представления результатов изучения поставленной задачи применялись методы количественного и качественного анализа, статистический метод.

Pезультаты и обсуждение / Results and discussion. Выход из финансовых кризисов сегодня осуществляется за счет роста американской валюты в международном обороте и эмиссии казначейских ценных бумаг США. Так, 2/3 выпущенных ФРС США 100-долларовых купюр обращается за рубежом [1]. В свете этого не стоит надеяться на то, что новая валютная система будет полностью абстрагирована от доллара, однако его роль с течением времени будет пересматриваться на фоне учреждения и использования других инструментов валютного и товарного рынка.

Финансовые коллапсы, накрывающие международные рынки, являются лакмусовой бумажкой, катализирующей процесс сокращения государствами доли американской денежной единицы в своих валютных резервах и уменьшения объема покупки казначейских обязательств США. Так, доля доллара в мировых валютных резервах с 2007 г., с момента начала мирового финансового кризиса, сократилась уже более чем на 5 \% [2]. Примечательным является факт резкого снижения вложений России в бумаги США. На март 2018 года у РФ было облигаций на $\$ 96,1$ млрд, в апреле этот объем упал до $\$ 48,7$ млрд, а майский показатель составил $\$ 14,9$ млрд, что явилось самым низким значением за последние 11 лет. По сравнению с пиковым значением в размере $\$ 176$ млрд, пришедшемся на октябрь 2010 года, сегодняшний оббъем вливаний в обязательства США почти в 12 раз меньше.

Заметным игроком, стремящимся изменить баланс сил среди ведущих резервных валют, является сегодня Китай, который держит курс на укрепление своей национальной валюты. Политика, в последнее время проводимая КНР и отдельными государствами азиатского региона, красноречиво свидетельствует о стремлении этих государств к уменьшению роли долларового режима. Доводами в пользу этого являются следующие факты:

1. Учреждение осенью 2014 года Азиатского банка инфраструктурных инвестиций (АПВ), участниками которого стали 57 стран с капиталом в размере 100 млрд долларов. Учредителями Азиатского банка инфраструктурных инвестиций стали Китай и 20 государств Азии, нацеленные создать конкуренцию Всемирному банку и МВФ на пути дедолларизации мировых финансов. США пытались противостоять возникновению нового глобального финансового центра, отговаривая многие страны от членства в данной организации. Сегодня к АПВ присоединились Россия, Бразилия, Египет, Индонезия, Иран, Израиль, Саудовская Аравия, ЮАР, Южная Корея, Турция.

Цель создания АПВ - инфраструктурные реформы в отстающих азиатских регионах, касающиеся прежде всего строительства дорог, развития телекоммуникационной инфраструктуры. Главенствующую роль в деятельности банка играет Китай, действующий в статусе многостороннего партнера.

2. Заключение стратегических международных сделок в валютах государств - участников сделки в обход долларовых транзакций. Примером такой сделки явилось соглашение между Российской Федерацией и КНР, утвердившими весной 2014 года условия крупнейшего газового договора: срок действующих поставок - 30 лет, объем поставляемого сырья - до 68 млрд куб. м в год (это составляет 11 \% совокупных китайских потребностей), а также условия оплаты, предполагающие расчеты в национальных валютах, а не в американских долларах. 
3. Расчеты посредством валютных свопов между центральными банками. Заинтересованный в проведении международных сделок в юанях, Китай подписывает валютные свопы с центральными банками, которые в свою очередь могут выдавать кредиты своим банкам в китайской валюте. Политика КНР в этом направлении нацелена прежде всего на страны Азиатско-Тихоокеанского региона и развивающиеся государства. К текущему моменту общее число действующих соглашений более 20 на сумму, превышающую 3,7 трлн юаней, в том числе и с Россией на 150 млрд юаней (\$25 млрд). Примечательно, что четыре года назад в денежном выражении валютные свопы были меньше в 350 раз.

Очевидно, что экономическая политика КНР в части дедолларизации американского денежного знака и интернационализации своей национальной валюты прослеживается сегодня наиболее явственно по сравнению с другими странами. В 2011 году только 900 финансовых учреждений имели дело с китайской денежной единицей, а три года спустя этот показатель приблизился к 10 тысячам организаций. Офшорные сделки с юанем оценивались на тот момент в 143 млрд долларов США. Кроме того, доля китайского экспорта и импорта, расчеты по которым осуществлялись в юанях, возросла почти в 6 раз за три года и составила $12 \%$ [3].

На мировой арене вопрос несоответствующего современным реалиям статуса доллара носит скорее теоретический характер, в отличие от Китая, шаги которого в направлении «остракизма» доллара подкреплены практическими действиями. Так или иначе дискуссии относительно пересмотра международного финансового устройства, активно ведущиеся еще с 2010 года в $\mathrm{OOH}$, об использовании единственной резервной валюты свидетельствуют о назревшем вопросе трансформации существующей Ямайской системы.

Идея создания новой международной резервной валюты набирает все больше сторонников. Среди существующих видений относительно ее будущих характеристик доминируют предложения о долевом участии нынешних резервных валют. Кроме того, некоторые эксперты настаивают на присутствии золота в составе глобальной денежной единицы. Призывы рассматривать золото в качестве одной из составляющих новой валютной системы не единичны в среде ведущих ученых и экономистов. В этой связи политика приращения золотых запасов отдельными государствами попадает под пристальное внимание со стороны аналитиков.

В условиях объективной деформации эмиссионного механизма США и за неимением ценностного эквивалента, позволяющего объективно устанавливать обменные курсы, золото отождествляют практически с единственным инструментом, способным идентифицировать истинную стоимость обращающихся на рынке денежных знаков. В этой связи управление золотыми авуарами становится важным элементом государственной политики, вбирающей в себя новое звучание. Не удивительно, что обладание золотом сегодня стало предметом жесткой конкуренции среди регуляторов и в развитых странах, и в странах с развивающейся экономикой. На текущий момент неоспоримое лидерство в этой конкуренции принадлежит развитым странам, у которых сосредоточена бо́льшая часть монетарного золота $(84,8$ \%) - авуары в металле у США составляют 8,1 тыс. т; Германии $-3,4$ тыс. т; Италии - 2,5 тыс. т; Франции - 2,4 тыс. т. Резервы эмитентов резервных валют состоят почти исключительно из золота, что является «скрытым обеспечением» их эмиссии (в резервах европейских стран доля золота достигает 70-80\%, у США - 90\%) [4]

Золото содержится в запасах многих стран по нескольким причинам. Первая: несмотря на то, что золото не выполняет более денежных функций и перешло в категорию “товар», оно является товаром с уникальными свойствами, такими как однородность, делимость, прочность, долговечность, неподверженность порче. Благодаря этим свойствам золоту присуща абсолютная ликвидность, которую признал в свою очередь Базель-3, закрепив за драгоценным металлом уровень риска, равный нулю. Высокий спрос и многочисленные каналы сбыта дают возможность реализовать золото в короткие сроки в обмен на требуемую валюту. 
Вторая: золото не может быть долговым обязательством кого бы то ни было, и его стоимость не зависит от финансового состояния субъекта, им обладающего. Третье, многие участники международного экономического рынка предполагают, что золото станет составляющим элементом нового мирового финансового устройства и в недалекой перспективе произойдет в той или ином роде монетизация металла [5].

Признание за золотом особой роли в свете ожидаемых трансформаций международной валютной системы подтверждено сменой финансового курса центральных банков в отношении политики управления официальными золотыми резервами: с 2009 года чистую продажу металла регуляторами заменило нетто-приобретение золота. Таким образом, в последние годы центробанки стали сильнейшими игроками на мировом рынке золота, совокупный объем золотых резервов по оценкам WGC сегодняшний день в хранилищах центральных банков составляет около 35 тысяч т металла.

Доводом в пользу не теряющего своих позиций золота могут служить факты признания МВФ китайского юаня резервной валютой и включение его с 1 октября 2016 года в число валют, используемых для расчета СДР. В числе этих фактов следует признать мировое лидерство Китая по темпам накопления драгоценного металла: согласно статистике МВФ в течение последних пяти лет хранилища Китая пополнились драгоценным металлом на 57 \%, и это пополнение происходит за счет самых высоких в мире показателей по добытому металлу.

Китайское руководство предпринимает активные меры по закреплению своей валюты в статусе международной, в том числе путем наращивания ускоренными темпами золота в своих хранилищах. Стремление Китая к мировому экономическому лидерству ограничено сегодня весомой зависимостью юаня от доллара, что подвергает его национальную валюту рискам колебания в случае возникновения глобальных финансово-экономических кризисов. Значительные объемы монетарного золота, которое сегодня играет роль своеобразного компенсатора дефицита национальных экономических суверенитетов, способны разрешить эту проблему [6].

Рассмотренная мировая практика в сфере обращения золота диктует необходимость совершенствования функциональной и организационной структуры рынка золота в Российской Федерации в русле аккумуляции драгоценного металла в качестве резервного актива. Политика России в части управления официальными золотыми запасами в последние годы претерпела значительные изменения: приращение официальных золотых резервов, являющееся плацдармом политики укрепления национальной валюты и необходимым условием ее ликвидности, осуществляется в русле гарантированного спроса на золото у отечественных золотодобытчиков со стороны государства, что, в свою очередь, является залогом стабильной золотодобычи.

На текущий момент Россия занимает пятое место в мире (на 6-м месте Китай) по официально заявленным запасам золота в резервах. По состоянию на 1 июля 2018 года золотой запас России составил 1944 т. Доля монетарного золота в общей стоимости золотовалютных резервов России составляет около 17 \% (в 2013 году доля золота была равна 8,9\% в золотовалютных резервах) [7].

Преимушества наращивания золотых запасов России в свете происходящей мировой трансформации рынка золота видятся в следующих плоскостях:

1) золото, обладая абсолютной ликвидностью, дает гарантию от нестабильности валютных курсов резервных валют, накопленных в активах Банка России. Никто сегодня не может гарантировать безоговорочную ликвидность ни доллара США, ни евро, ни японской иены, в отличие от золота;

2) абсолютные и относительные показатели объемов золота в составе национальных международных резервов напрямую формируют обеспеченность национальной валюты, уровень ее конвертируемости и весомости в международной торговле. Фактор «золотой») состоятельности России влияет на оценку инвестиционного рейтинга страны, сигнализирующего об условиях привлечения иностранных финансовых ресурсов на российский рынок; 
3) санкционная политика Запада в отношении России не исключает наложение запрета на использование зарубежных валютных активов РФ. В этой связи официальный запас золота России, локализованный на территории страны, становится неоспоримым активом, гарантирующим исполнение государственных обязательств;

4) прогнозная цена на золото с течением времени будет расти, это обстоятельство также должно быть учтено в свете политики приращения металла. Сегодня текущая ценовая конъюнктура на золото позволяет Банку России приобретать этот ликвидный актив при ценовых минимумах;

5) достаточные объемы золотых авуаров позволяют России рассчитывать на роль маркет-мейкера. Приобрести независимость от ценовой волатильности рынка золота, обладая достаточным золотым запасом, Россия может путем формирования внутренних механизмов фиксинга на золото на площадке Московской биржи. Собственную процедуру фиксинга золота в России необходимо направить на снижение рисков при заключении сделок с драгметаллом и его хеджировании российскими предприятиями, что позволит в большей степени заинтересовать суб̋ъектов в работе на российском рынке золота.

Заключение / Conclusion. Манипуляциям с золотом, начавшимся еще в 1970-х годах, противостоит политика стран, сопротивляющихся долларовому господству. Значимость драгоценного металла как неотъемлемого элемента валютно-финансовой системы не утрачена по сей день, более того, в свете меняющейся политической и экономической мировой конъюнктуры эта значимость только возрастает.

В условиях существующей неопределенности в отношении мировых валют политика России в отношении золота представляется своевременной и перспективной. Косвенным подтверждением ей служит, с одной стороны, высокая доля золота в резервах развитых стран, с другой стороны, тенденция покупки золота центральными банками мира. Потенциал доли роста металлического компонента за счет внутренних источников в международных резервах у России еще большой: потребуется не один год, чтобы приблизиться к ведущим экономикам по показателю доли золота в международных резервах. Причисление России к тандему стран-лидеров по накопленным запасам золота позволит занять ей не только значимое место в современной структуре глобальных и региональных рынков, обеспечить необходимый страховой задел от геополитических и геоэкономических рисков, но и уменьшить размер чистого кредита в пользу эмитентов резервных валют.

\section{ЛИТЕРАТУРА И ИНТЕРНЕТ-РЕСУРСЫ}

1. Красавина Л. Н. Концептуальные подходы к реформированию мировой валютной системы // Деньги и кредит. 2010. № 5. С. 48-57.

2. Мануков С. Доля евро и доллара в мировых резервах снизилась до 15-летнего минимума // «ExpertOnline». 2016. URL: http://expert.ru/2016/06/8/dollar-evro (дата обращения - 14.08.2018).

3. Китай нанес новый удар по нефтедоллару // Вести. Экономика. URL: http://www.vestifinance.ru/ articles/60057 (дата обращения - 18.07.2018).

4. Алферов В. Т., Навой А. В. Золото в структуре международных резервов Российской Федерации: трансформация подходов к управлению // Деньги и кредит. 2014. № 10. С 55.

5. Паршина Л. Н. Роль золота в резервах стран // Финансы и кредит. 2016. № 2. С. 4.

6. Еськова П. Роль золота в современной экономике: подтверждение значимости // Российский экономический журнал. 2015. № 6. С. 105.

7. Международные резервы Российской Федерации - Официальный сайт Центрального банка России. URL: http://www.cbr.ru>hd_base/mrrf (дата обращения - 02.08.2018).

\section{REFERENCES AND INTERNET RESOURCES}

1. Krasavina L. N. Konceptual'nye podhody $\mathrm{k}$ reformirovaniyu mirovoj valyutnoj sistemy (Conceptual approaches to the reform of the world monetary system) // Dengi i credit. 2010. № 5. Pp. 48-57. 
2. Manukov S. Dolya evro i dollara v mirovyh rezervah snizilas' do 15-letnego minimuma (The share of the Euro and the dollar in world reserves fell to a 15-year low) // «Expert Online». 2016. URL: http://expert. ru/2016/06/8/dollar-evro (date of access - 14.08.2018).

3. Kitaj nanes novyj udar po neftedollaru (China struck a new blow to the oil dollar) // Vesti. Economika. URL: http://www.vestifinance.ru/articles/60057 (date of access - 18.07.2018).

4. Alpherov V. T., Navoi A. V. Zoloto v strukture mezhdunarodnyh rezervov Rossijskoj Federacii: transformaciya podhodov $\mathrm{k}$ upravleniyu (Gold in the structure of international reserves of the Russian Federation: transformation of management approaches) // Dengi i credit. 2014. № 10. P. 55.

5. Parschina L. N. Rol' zolota $v$ rezervah stran (The role of gold in country reserves) // Finance and credit. 2016. № 2. P. 4.

6. Eskova P. Rol' zolota v sovremennoj ehkonomike: podtverzhdenie znachimosti (The role of gold in the modern economy: confirmation of the importance) // Russian economic journal. 2015. № 6. P. 105.

7. Mezhdunarodnye rezervy Rossijskoj Federacii (International reserves of the Russian Federation) - Official website of the Central Bank of Russia. URL: http://www.cbr.ru/hd_base/mrrf (date of access - 02.08.2018).

\section{СВЕДЕНИЯ ОБ АВТОРЕ}

Плешивцева Анна Алексеввна, соискатель ФГАОУ ВО «Южный федеральный университет», г. Ростов-на-Дону. E-mail: pleshivtseva_anna@mail.ru

\section{INFORMATION ABOUT AUTHOR}

Anna Pleshivtseva, applicant is Federal State Autonomous Educational Institution Higher Education «Southern Federal University», Rostov-on-Don. E-mail: pleshivtseva_anna@mail.ru 